skilled workmen the difficulties of manipulation were not such as could not be got over, and that fairly uniform results would follow reasonable care in working.

The next business was the reading of Prof. Roberts-Austen's paper on the recording pyrometer. It will be remembered that at the annual meeting of two years ago, Prof. Roberts Austen gave a description of the Le Chatelier pyrometer, and the application of it, which he had introduced, by which it was adapted for recording work in blast furnace practice. The object of the present paper was to give some particulars of the most recent form of this recording pyrometer, which Prof. Roberts-Austen has devised. At the request of Mr. E. P. Martin, Managing Director of the Dowlais Iron Works, Cardiff, an instrument was made and put into operation as a means of recording temperature of the blast in an iron smelting furnace. The spot of light from the mirror of a galvonometer is thrown on sensitised paper, the paper itself being traversed at a uniform speed. In this way the record of temperature at all times is obtained. The author gave an instance of the value of the instrument. The blast to the furnace in question was supplied by a number of hot blast stoves on the ordinary regenerative principle. When the chequer work in a stove has been heated up sufficiently and the blast is first turned on for supply of the furnace, the temperature of the blast is naturally at its maximum. As the blast cools the chequer work, by abstracting heat from it, the temperature gradually falls, and it continues to decrease until it is considered desirable to re heat the stove, and then a new stove is switched on. It will be seen therefore, that the temperature of the blast in the main, common to two or more stoves, will vary regularly, so that a curve on the diagram indicating temperature, will consist of a number of more or less steep inclinations; in fact, very much representing the teeth of a saw. That would be the normal inclination; occasionally, however, the gas valves leak, and then the stove may be receiving hot gases when it ought only to be passing air. The average temperature when this leaky stove is in use will naturally be higher than that due to another stove; in fac', it will be heated at the expense of the remaining number of the group. The result is antagonistic to regular working which is so much desired in blast furnace practice, and though the evil effect may be neutralised by the heat absorbing property of the large mass of material in the blast furnace-acting, as it were, as a flywheel for heat-the state of irregularity, if carried to excess, might be very harmful. It is also, of course, desirable that the blast furnace operator should know at the earliest time when his valves are going wrong; in fact, the whole system upon which the Cowper stove is based bears on the proper reversal of the blast. Prof. Rubert Austen's apparatus fulfils the required conditions in supplying the knowledge required, and the in vention cannot fail to be one of the greatest service to the metallurgist.

A paper hy $\mathrm{Mr}$. John Head on puddling iron was next read and was followed by a short discussion, after which the meeting concluded with the usual votes of thanks.

\section{ROYAL GEOGRAPHICAL SOCIETY} ANNIVERSARY MEETING.

THE anniversary meeting of the Royal Geographical Society held on Monday afternoon was, as we anticipated, exceptionally large and representative. The report of the council stated that the membership of the Society on the Ist of May was 369 r (including 22 ladies), a net increase of 166 fellows since May 1st, 1892 , being the largest net addition to the membership of the Society since 1875 . The total net income for the year was $\mathscr{L}_{93}, 000$, and the expenditure $£ 9012$. In addition to the services performed to the fellows and the public by means of evening meetings, the use of the Map Room and Library and the publication of the Geographical fournal, twenty four intending travellers have received instruction in practical astronomy and route-surveying from $\mathrm{Mr}$. Coles, and instruments have been lent to eleven travellers for use in all parts of the world.

In order to express disapproval of the words we italicise in the first paragraph of the report, which ran as follows:-

Membership. - The question of electing Ladies as Ordinary Fellows was considered by a Special General Meeting on April $24^{\text {th, }}$ when it was decided in the negative by a considerable majority. The Council regard this vote (unless hereafter

No. 1231, VOL. 48] rescinded by a General Meeting) as conclusive against any further election of Ladies as Ordinary Fellows, zvithout prejudice to the status of those already elected. They consider that, under the circumstances, all the legal expenses incurred in connection with this important question may equitably be defrayed by the Society, and they have accordingly provided for their being so defrayed.

Mr. Dibden, seconded by Colonel Montague, moved the rejection of the report, but on a division being taken the report was accepted by a large majority. The medals and other awards for the year were then presented as follows :-

The Founder's MedaI, to Frederick Courtney Selous, in recognition of his extensive explorations and surveys in British South Africa. The Patron's Medal, to W. Woodville Rockhill, for his travels and explorations in Western China, Kokonor, Tsaidam and N.E. Tibet. The Murchison Grant tor I893, to Mr. R. W. Senior, who, for several years in succession, has carried out a most laborious duty in the higher ranges of Kulu and Lahaul, Punjab Himalayas, and the results achieved in point of accuracy, expedition, and amount of work done, have been exceptional in the face of great hardships and great physical difficulties. The Gill Memorial, to Mr. Henry O. Forbes, for his explorations and natural history ohservations in New Guinea, the Malay Archipelago, and the Chatham Islands. The Cuthbert Peek Grant, to Mr. Charles Hose, for explorations and natural history observations and collections in Saráwak, North Borneo. Six prizes of $£ 5$ each, and eight of books, given by the Royal Geographical Society to Students in Training Colleges for 1893 , were presented to the successful candidates who were introduced by Mr. Mackinder.

A ballot was then taken for the election of officers and council for the ensuing year, and the list proposed by the council was, as usual, adopted. The new president is Mr. Clements R. Markham, F.R.S., and the vice-presidents are the Hon. G. C. Brodrick, Sir Joseph Hooker, F. R.S., Sir John Kirk, F.R.S., Dr. W. T. Blanford, F.R.S., General R. Strachey, F.R.S., and Captain W. J. L. Wharton, F.R.S.

Sir M. E. Grant Duff, the retiring president, then read the anniversary address on the progress of geography, in which he summarised the various activities of the Society. In the course of this he said that during the four years in which he had the honour to be president, he had seen the number of Fellows increase by three hundred and fifty-eight, and they were now close upon three thousand seven hundred. Before long the Society would have to take into the most serious consideration the acquisition of a new domicile. "Our constantly increasing collections would of themselves, as I have pointed out before, ere long drive us from our present quarters, and we have, in addition, reason to believe that even if we could extend our borders where we now are, on anything like reasonable terms, which we cannot, certain changes in the streets in this part of the town would ere long improve us off the face of creation. Then, although the University of London has been most kind to us in lending us their theatre, and although the character of our papers and of our publications, as well as our position as the leading geographical society of the world make us, I think, not unworthy recipients of the kindness of a university, whose operations extend over the whole of the British Empire, we cannot look forward to the present state of things continuing for an indefinite period. A vote of the Senate might at any time put an end to it."

An epitome of the year's exploration-which has been sufficiently recorded in our "Geographical Notes" from week to week - concluded the address, which was received with great applause. On the motion of Lord Northbrook, seconded by Sir John Lubbock, an enthusiastic vote of thanks was passed to the retiring president, who briefly replied.

At this stage a controversy regarding the question of the admission of women to the Society was started, and after some spirited speaking, the leading opponents of the recent action of the council stated that they were perfectly prepared to concur with the wishes of a majority of the Society as ascertained by means of a plébiscite, or a special general meeting to be con. vened at an early date.

\section{UNIVERSITY AND EDUCATIONAL INTELLIGENCE.}

OXFORD. - The number of entries for the Honour School of Natural Science this year is $4 \mathrm{I}$, which compares favourably with 